\title{
Inter-annual variability of the Pelagic-Benthic coupling in the upwelling system off central Chile
}

\author{
M. Graco ${ }^{1}$, D. Gutiérrez ${ }^{1}$, and L. Farías ${ }^{2}$ \\ ${ }^{1}$ Dirección de Investigaciones Oceanográficas- CENSOR Project, Instituto del Mar del Perú, P.O. Box 22, Callao, Perú \\ ${ }^{2}$ Departamento de Oceanografia- COPAS, Universidad de Concepción, Concepción, Chile
}

Received: 3 August 2005 - Revised: 5 December 2005 - Accepted: 6 December 2005 - Published: 23 January 2006

\begin{abstract}
The coastal region of central Chile $\left(36^{\circ} \mathrm{S}\right)$ is one of the most productive coastal systems, characterized by a marked seasonality in the upwelling regime, that brings subsurface waters rich in nutrient and poor in oxygen (ESSW) into the euphotic zone. This oceanographic condition depends basically on the equatorward wind strength and is modified on different time scales, with the El Niño-Southern Oscillation (ENSO) phenomenon as the main source of interannual variability in the Pacific Ocean. Here we present an effort to integrate physical and biogeochemical variability associated with in situ information and experiments at coastal stations off central Chile $\left(36^{\circ} \mathrm{S}\right)$ in order to improve the knowledge on the pelagic-benthic coupling in this upwelling system during the warm ENSO phase or El Niño. Carbon fluxes exported from the water column to the sediments and the ammonium exchange across the sediment-water interface are discussed together with oceanographic and benthic conditions. All measurements and estimations were carried out from May 1997 until April 2001 at two stations, one located inside Concepción Bay ( $\sim 28 \mathrm{~m}$ depth), and the other on the continental shelf at $\sim 36^{\circ} \mathrm{S}(\sim 88 \mathrm{~m}$ depth). The results show that the pelagic and benthic systems are strongly coupled off central Chile $\left(36^{\circ} \mathrm{S}\right)$. Oceanographic variability associated with upwelling events (seasonal scale) and an El Niño event (interannual scale) was observed. The carbon fluxes exported to the sediments, the benthic conditions (i.e., quantity and quality of the sediment organic matter), and the ammonium exchange across the sediment-water interface, responded to the seasonal regime of upwelling during non El Niño years as well as to the ENSO related oceanographic variability.
\end{abstract}

Correspondence to: M. Graco

(mgraco@imarpe.gob.pe)

\section{Introduction}

The coastal upwelling zone of the Humboldt Current System (HCS) in the eastern South Pacific Ocean attracts considerable scientific interest, particularly the coastal region off central Chile $\left(36^{\circ} \mathrm{C}\right)$. This area presents one of the highest biological productivities [1-19.9 $\mathrm{g} \mathrm{C} \mathrm{m}^{-2} \mathrm{~d}^{-1}$ (Pantoja et al., 1987; Peterson et al., 1988; Fossing et al., 1995; Daneri et al., 2000), and a pronounced and shallow oxygen minimum zone $\left(\mathrm{O}_{2}<45 \mu \mathrm{M}\right)$ that influence one of the widest continental shelves off Chile (Ahumada and Chuecas, 1979). Two physical processes appear to be responsible in coastal upwelling areas for enhanced productivity (Barber and Chavez, 1983): (1) a shallow (40-80 m) nutricline so that (2) upwelling favourable winds can draw nutrient-rich waters into the euphotic zone.

The region off central Chile $\left(36^{\circ} \mathrm{S}-42^{\circ} \mathrm{S}\right)$ is characterized by a marked seasonality in the upwelling regime that depends basically on the equatorward wind strength. Additionally, this oceanographic condition can be modified on different time scales, principally by the El Niño-Southern Oscillation (ENSO) (Shaffer et al., 1997; Shaffer et al., 1999). During El Niño, wind field anomalies in the western equatorial Pacific generate Kelvin waves, that propagate eastward deepening the thermocline and the nutricline (MacPhaden, 1999). Anomalous ocean conditions can persist for 6-18 months and they result in warm and nutrient poor waters feeding the upwelling and large reductions of plankton, fish and sea birds in the normally productive upwelling region (Barber and Chavez, 1983).

During the 1997-1998 El Niño, warm and more oxygenated waters and anomalous local winds were observed off central Chile $\left(36^{\circ} \mathrm{S}\right)$ (Escribano et al., 2004). Changes in the composition and distribution of the macrofauna and meiofauna were observed during this period in the study area (Gutiérrez et al., 2000; Neira et al., 2001). Additionally, the benthic system showed a decrease in the organic matter remineralization rates, ammonium production and denitrification 


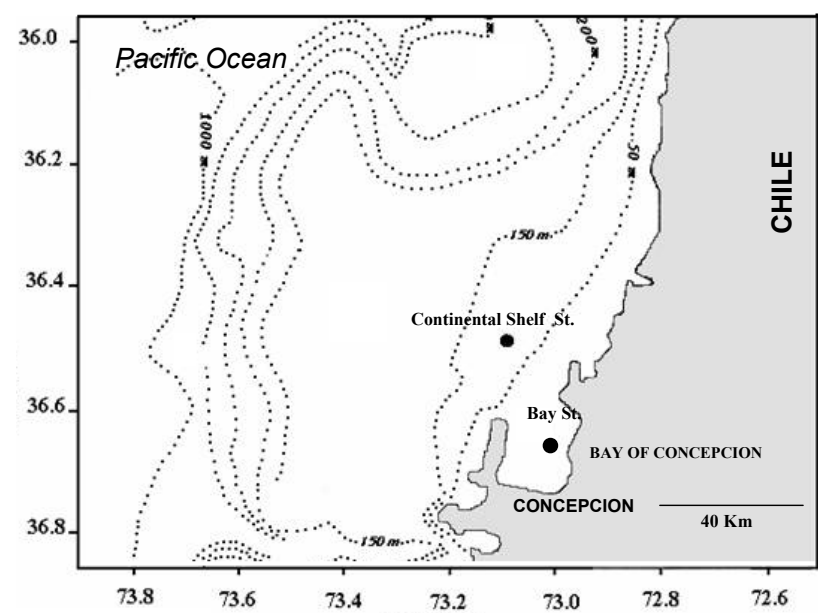

Fig. 1. Location of the sampling stations in Concepción Bay $(\sim 28 \mathrm{~m})$ and on the continental shelf $(\sim 88 \mathrm{~m})$ off central Chile.

rates (Graco, 2002; Farías et al., 2004). In order to obtain a better understanding of the pelagic-benthic coupling and its variability, and the El Niño effect in the coastal upwelling area off central Chile $\left(36^{\circ} \mathrm{S}\right)$, here we present and analyze a temporal data set of temperature, dissolved oxygen and nutrients in the water column, carbon fluxes exported to the sediments, sediment organic matter and sediment-water nitrogen fluxes from May 1997 until April 2001.

\section{Materials and methods}

\subsection{Sample collection and observations}

Time series were established at two coastal locations off central Chile (Fig. 1), one in the Bay of Concepción $\left(36^{\circ} 38.7^{\prime} \mathrm{S}\right.$, $73^{\circ} 2.2^{\prime} \mathrm{W}, 28 \mathrm{~m}$ depth) and the other on the continental shelf $\left(36^{\circ} 30.8^{\prime} \mathrm{S}, 73^{\circ} 7.7^{\prime} \mathrm{W}, 88 \mathrm{~m}\right.$ depth). Observations started in May 1997 and continued until April 2001, with a seasonal resolution of three months on board the research vessel "Kay Kay" (Universidad de Concepción). Discrete water samples were collected in Niskin bottles from various depths $(0,5,15$, $30,50,70,75,80,85-88 \mathrm{~m}$ ) and used to determine dissolved oxygen $\left(\mathrm{O}_{2}\right)$ and nutrient $\left(\mathrm{NO}_{3}^{-}, \mathrm{NO}_{2}^{-}\right)$concentrations. Water temperature was recorded with a CTD.

\subsection{Sediment Chl-a and carbon fluxes}

A SMBA multi-core, model MC 600, was used to recover undisturbed sediments cores of $50-60 \mathrm{~cm}$ in length (inner diameter $7.2 \mathrm{~cm}$ ). Sediment cores were sub-sampled for Chlorophyll-a (Chl-a) and Phaeopigment (Phaeop) measurements. Two cores $(3.6 \mathrm{~cm}, 20 \mathrm{~cm}$ length) were cut into $1-\mathrm{cm}$ thick slices (to a depth of $15 \mathrm{~cm}$ ) and the slices were used to determine water content, porosity, wet bulk density and Chl-a and Phaeop content. The pigments were measured by fluorometry and pools of labile Chl-a in sediments were estimated by integrating $15 \mathrm{~cm}$ of the sediment (Gutiérrez 2000).
Carbon fluxes exported to the sediments were estimated from sediment Chl-a pool sizes. The assumptions were:

$$
\begin{aligned}
& d I / d t=F-K I \quad \text { (Sun et al., 1994) } \\
& I=\text { Chl-a pool size }\left(\mathrm{mg} \mathrm{Chl-a} \mathrm{cm}{ }^{-3} \mathrm{~d}^{-1}\right) \\
& F=\text { Chl-a flux to the sediment ( } \mathrm{mg} \mathrm{Chl-a} \mathrm{cm}^{-3} \mathrm{~d}^{-1} \text { ) } \\
& K=\text { degradation rate of Chl-a (anoxic) } \\
& \text { (0.055 d } \mathrm{d}^{-1} \text {; Gutiérrez, 2000) }
\end{aligned}
$$

The Chl-a fluxes were transformed in carbon (C) fluxes (phytoplankton) using a ratio $\mathrm{C} / \mathrm{Chl}-\mathrm{a}=42.5$, which is a conversion factor for the area (Bernal et al., 1989), and falls within the range of values estimated for coastal areas (2652; Sun et al., 1994).

\subsection{Benthic ammonium fluxes}

The cores were transported to the laboratory within $3 \mathrm{~h}$ of sampling, wrapped in aluminum foil to exclude light, and placed into a thermo-regulated water bath at the in situ bottom temperature. Before running the incubations, the core samples were left 6-12 h with the bottom water taken from above the sediments; the $\mathrm{O}_{2}$ level was kept at the in situ concentration by bubbling with a mixture of $\mathrm{O}_{2}$ and Argon (Ar). The overlying water was continuously monitored for $\mathrm{pH}, \mathrm{T}^{\circ}$, and dissolved $\mathrm{O}_{2}$ concentration. Net rates of sediment-water exchange of $\mathrm{NH}_{4}^{+}$were measured by triplicate in short incubations (3-6h). A magnetic stirrer gently mixed the water in order to maintain the in situ dissolved $\mathrm{O}_{2}$ and nutrient distributions adjacent to the sediment surface.

\section{Results}

\subsection{Inter-annual and seasonal oceanographic variability}

The time series of water column temperature, dissolved oxygen, and nitrate in Concepción Bay and at the continental shelf stations are shown in Fig. 2. During 1997-1998, a slight warming of surface waters $\left(>13^{\circ} \mathrm{C}\right)$ was observed in summer (e.g., March 1998) but also in winter (e.g., June 1997), coinciding with higher temperatures in the bottom waters $\left(+2^{\circ} \mathrm{C}\right)$ than during the respective period of 1999 . In addition to the deepening of the thermocline during 1997-1998 at both stations, we observed a marked deepening of the oxygendeficient water mass distribution $\left(<45 \mu \mathrm{M} \mathrm{O}_{2}\right.$, Fig. 2). In fact, during 1997 and the first half of 1998 the water column was dominated by oxygenated waters, with oxygen deficiency only detected in the bottom waters (e.g., in March 1998).

During 1999 and 2000, we observed the expected dissolved oxygen seasonal pattern associated with favourable upwelling periods (spring-summer) and the influence of the Equatorial Subsurface Waters (ESSW) on the continental shelf. Spring and summer were characterized by hypoxic 

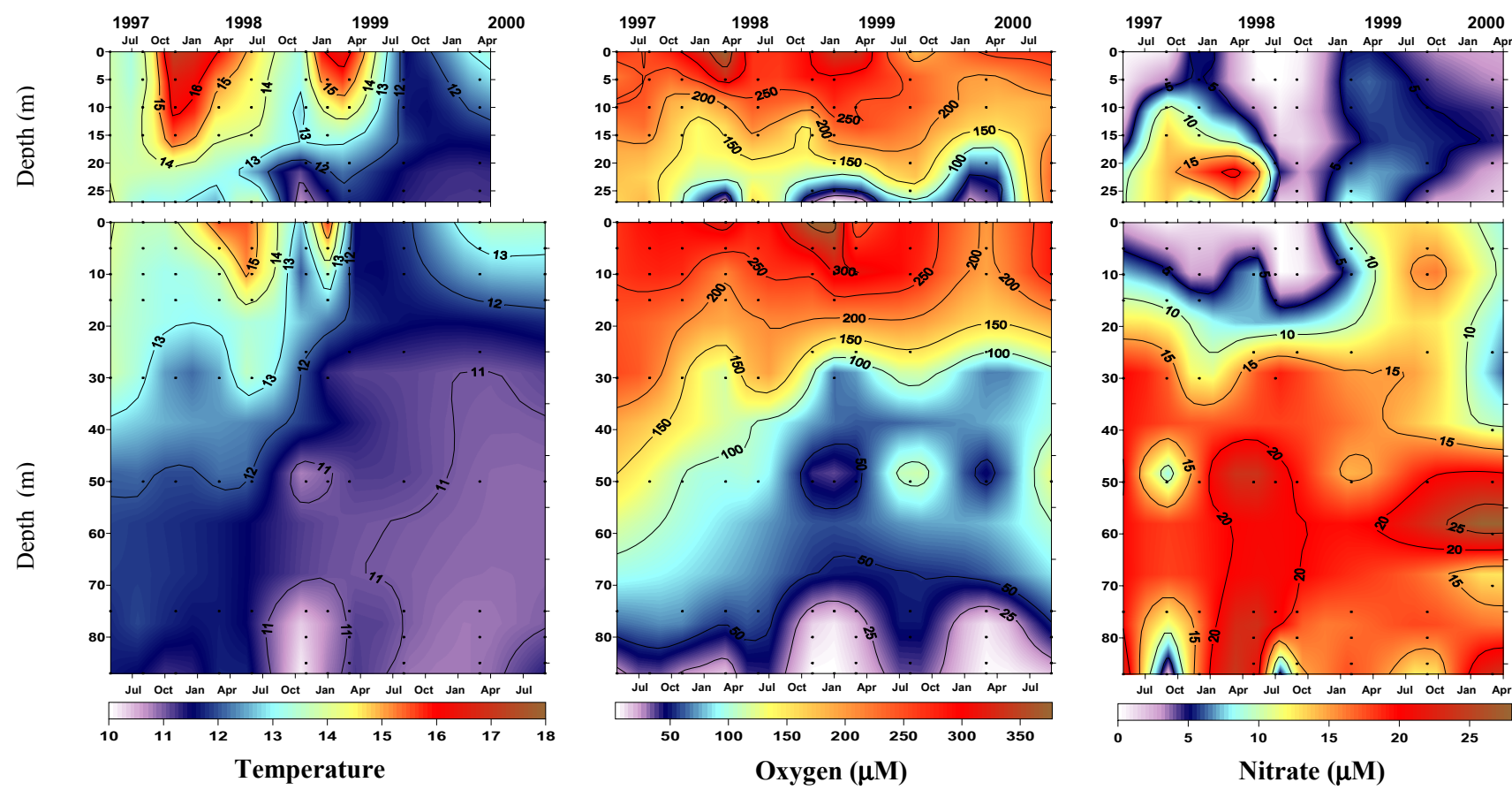

Fig. 2. Temporal variation of temperature, dissolved oxygen and nitrate in the water column of Concepción Bay (upper graphics) and the continental shelf (lower graphics).

waters $\left(<45 \mu \mathrm{M} \mathrm{O}_{2}\right)$ below $30 \mathrm{~m}$, and sub-oxic to anoxic bottom waters $\left(10-<3 \mu \mathrm{M} \mathrm{O}_{2}\right)$. In contrast during winter a more oxygenated water column was observed, with the presence of hypoxic conditions only in the bottom waters. The nitrate concentrations in the water column, considered as a signature of the occurrence and status of the upwelling events (i.e., relaxed or active phase, Peterson et al., 1988), presented two conditions in the surface waters during the study (Fig. 2): (1) High concentrations as expected due to the presence of upwelling events (15-25 $\mu \mathrm{M} \mathrm{NO}_{3}^{-}$), such as during spring of 1998 and summer of 2000, and (2) low nitrate concentrations ( $<10 \mu \mathrm{M} \mathrm{NO}_{3}^{-}$) as was observed during 1997 and during the summers of 1998 and 1999. These low nitrate concentrations could arise due to the uptake of primary producers (see below) or to changes in the chemical properties of the upwelled waters (e.g., El Niño). Additionally, nitrate depletion in the entire water column was observed on the continental shelf during March 1998. With the exception of March 1998 and January 1999 significant nutrient concentrations were present at depth (up to $26 \mu \mathrm{M}$, Fig. 2).

\subsection{Sediment chlorophyll-a content and pelagic carbon fluxes}

With the exception of 1997-1998, a strong seasonal pattern was observed in the chlorophyll-a (Chl-a) of the surface sediments. A maximum content of fresh organic matter, indicated by high Chl-a values and low Phaeop/Chl-a ratios $(<3.5-8$; Fig. 4), occurred during summer, one order of magnitude (in the bay) and 2-3 times (on the continental shelf) higher than during winter. During 1997 and 1998, a lower Chl-a content in the sediment $\left(<0.5 \mathrm{mgg}^{-1}\right.$ in the Bay and $<0.05 \mathrm{mg} \mathrm{g}^{-1}$ on the continental shelf) and a higher Phaeop/Chl-a ratio (6-11, Fig. 4) were estimated, significantly correlated (at $99 \%$ level) with the low in situ primary production reported in the area $(\mathrm{O}$. Ulloa, personal communication) and in the same range as the winter values (Fig. 4). During summer of 1997 and 1998, the expected high Chl-a sediment content and the flocculent layer development were not observed.

The carbon fluxes exported from the pelagic system to the sediment were calculated from the labile Chorophyll-a (Chla) pools in the sediments (Fig. 3). At both stations, the carbon fluxes $\left(0.5 \mathrm{~g} \mathrm{C} \mathrm{m}^{-2} \mathrm{~d}^{-1}\right.$ and $\sim 2 \mathrm{~g} \mathrm{C} \mathrm{m}^{-2} \mathrm{~d}^{-1}$ in the continental shelf and in the bay respectively) were 3 to 8 times lower than during the summers of 1999 and 2000 and within the range of winter fluxes $\left(0.5-0.9 \mathrm{~g} \mathrm{C} \mathrm{m}^{-2} \mathrm{~d}^{-1}\right)$. In the case of Concepción Bay, a flocculent layer (phytodetritus) was observed at the sediment-water interface during summers of 1999 and 2000. This flocculent layer resulted from very high carbon fluxes exported from the water column (up to $7 \mathrm{~g} \mathrm{C} \mathrm{m}^{-2} \mathrm{~d}^{-1}$ ), which are 4-6 times higher than the carbon fluxes reported on the continental shelf.

\subsection{Nitrogen fluxes across the sediment-water interface}

The ammonium fluxes (mean rates \pm standard deviations) are shown in Table 1. During 1999 and 2000, $\mathrm{NH}_{4}^{+}$effluxes (positive fluxes) occurred during summer periods, both in Concepción Bay (up to $36.6 \mathrm{mmol} \mathrm{m}^{-2} \mathrm{~d}^{-1}$ ) and on the continental shelf (up to $10.4 \mathrm{mmol} \mathrm{m}^{-2} \mathrm{~d}^{-1}$ ). During springsummer 1998, the fluxes were significantly lower at both 

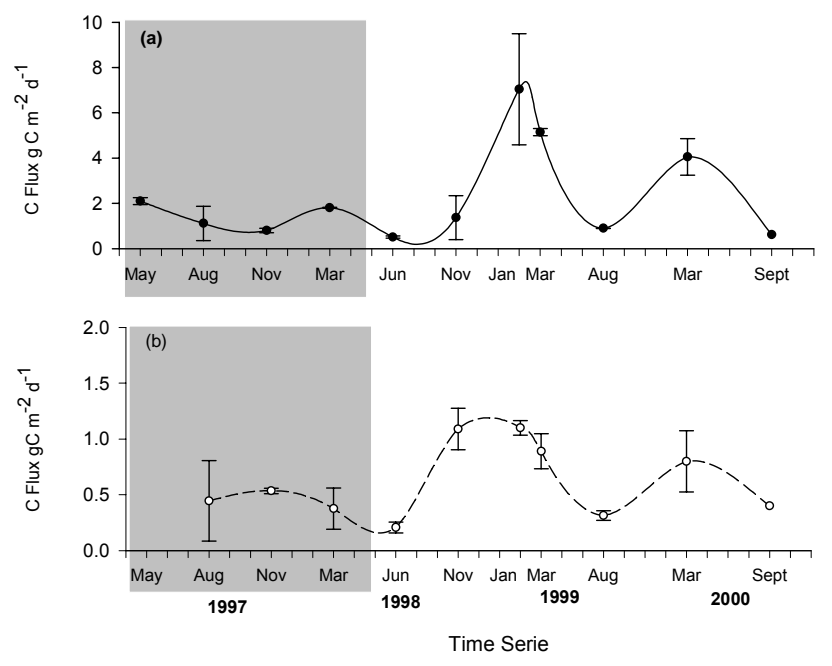

Fig. 3. Temporal variation of phytoplankton carbon fluxes, estimated from reactive Chlorophyll-a (Chl-a) pools in the sediments of the study areas. The grey area indicates the 1997-1998 El Niño influence. (a) Concepción Bay and (b) Continental shelf.

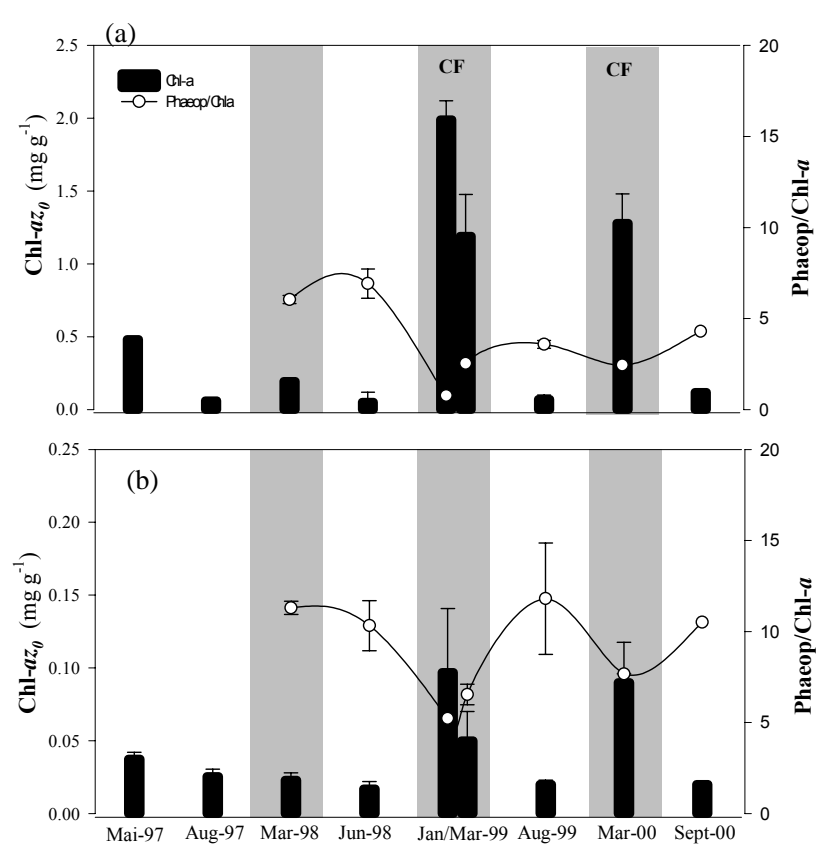

Fig. 4. Temporal variation of surface sediment Chl-a and Phaeop/Chl-a ratio in Concepción Bay (a) and on the adjacent shelf (b). The grey area indicates the favourable upwelling period (summer time).

stations. The fluxes were negative during winter of 1998 in Concepción Bay and during summer and winter periods of 1998 on the continental shelf (up to $-14.7 \mathrm{mmol} \mathrm{m}^{-2} \mathrm{~d}^{-1}$ ).
Table 1. $\mathrm{NH}_{4}^{+}$flux rates $\left(\mathrm{mmol} \mathrm{m} \mathrm{m}^{-2} \mathrm{~d}^{-1}\right)$ across the sedimentwater interface in Concepción Bay and on the continental shelf.

\begin{tabular}{ccccc}
\hline \multirow{2}{*}{ Sampling period } & \multicolumn{2}{c}{ Bay of Concepción } & \multicolumn{2}{c}{ Continental Shelf } \\
& Mean & S.D. & Mean & S.D. \\
\hline Mar 1998 & 2.3 & 0.4 & -14.7 & 3.7 \\
Jun 1998 & -7.6 & 4.9 & -4.7 & 2.8 \\
Nov 1998 & 2.0 & 0.9 & 2.9 & 1.1 \\
Jan 1999 & 36.7 & 6.4 & 10.4 & 2.7 \\
Mar 1999 & 20.8 & 6.1 & 10.4 & 1.8 \\
Aug 1999 & 6.21 & 1.9 & -5.7 & 1.8 \\
Mar 2000 & 21.9 & 3.4 & 6.6 & 1.1 \\
Sep 2000 & 3.9 & 1.59 & -0.4 & 0.7 \\
Apr 2001* & 5.6 & 0.8 & 2.1 & 0.1 \\
\hline
\end{tabular}

S.D. Standard deviation.

* Taking from Molina (2002).

\section{Discussion}

4.1 Physical, chemical and primary productivity variability from 1997 to 2000

The oceanographic conditions off central Chile $\left(36^{\circ} \mathrm{S}\right)$ fluctuate on different time scales (seasonal, intraseasonal, interannual) (Strub et al., 1998). A marked seasonality in the oceanographic conditions was described previously (Ahumada et al., 1991; Daneri et al., 2000) and is associated with the predominance of southwesterly winds during the austral spring and summer periods causing the upwelling of Equatorial Subsurface Waters (ESSW) (Ahumada and Chuecas, 1979; Arcos and Salamanca, 1984; Arcos and Wilson, 1984; Peterson et al., 1988; Sobarzo et al., 1997). Herein, we present results that show the notorious influence of seasonal variability on the dissolved oxygen, temperature and carbon exported from the water column to the sediments, both on the continental shelf and in Concepción bay during 1999 and 2000. During the 1999 and 2000 summer and spring periods, the water column was dominated by oxygen deficient conditions, low temperatures and high nitrates (Fig. 2), all features that are characteristic of the ESSW. Additionally, high fluxes of carbon exported to the sediments during this period were higher than during winter, by two or three times on the continental shelf and by up to eight times in the bay (Fig. 3), suggesting the imprint of the primary production (PP) seasonality. In fact, PP in the area presents a significant variability influenced by the upwelling events, reaching rates of $\sim 4 \mathrm{~g} \mathrm{C} \mathrm{m}^{-2} \mathrm{~d}^{-1}$ in summer and rates as low as $0.4 \mathrm{~g} \mathrm{C} \mathrm{m}^{-2} \mathrm{~d}^{-1}$ during winter (Farías et al., 2004). These high rates of PP can explain the nitrate deficit observed in the surface water layer during summer 1999 and 2000 (Fig. 2).

A different scenario was observed during 1997-1998 in the coastal waters of central Chile, with warmer temperatures $\left(>14^{\circ} \mathrm{C}\right)$ and low nitrate values in the surface layers and also in the bottom waters (Fig. 2). The deepening in the thermocline was coincident with a deepening of the oxygen deficient 
waters as shown in Fig. 2. We ascribe this drastic change in the oxygen values and the thermal anomalies to the perturbations associated with the 1997-1998 El Niño. The thermal anomaly $\left(2-3^{\circ} \mathrm{C}\right.$ higher) observed was reported before in central Chile as a signature of an El Niño event ...(Fonseca and Farías 1987), as well as the increase in the oxygen bottom water conditions (Gutiérrez et al., 2000). The same pattern of changes was also reported in the eastern SouthPacific off Peru during the 1982-1983 El Niño (Barber and Chavez, 1983). A deepening of the nutricline is expected during El Niño, and consequently a general decrease in the PP (Barber and Chavez, 1983; Chavez et al., 2002). We have found a change in the water column nutrient distribution during 1997 and the first half of 1998, coincident with low carbon fluxes exported to the sediment. Furthermore, during 1997 and the first half of 1998 there was not a seasonal change in the carbon exported. The values were significantly lower than those observed during the upwelling favourable summers of 1999 and 2000 (Fig. 3). These low carbon fluxes suggest a decrease in the PP rates. Data from the continental shelf during 1998 show PP rates in the range of the values observed during winter of non-El Niño years $\left(<0.2 \mathrm{~g} \mathrm{C} \mathrm{m}^{-2} \mathrm{~d}^{-1}\right)$ (Farías et al., 2004).

\subsection{A tight pelagic-benthic coupling in the central area off Chile}

As well as the pelagic system, the benthic system could reflect the variability in the oceanographic conditions due to the pelagic-benthic coupling existing or the energy and mass transfer between both systems. In this respect our data show a conspicuous seasonal change in the fresh organic matter loaded to the sediments, indicated by Chlorophyll-a (Chl-a) and Phaeopigment (Phaeop) contents. Significant Chl-a concentrations and low Phaeop/Chl-a ratio were characteristics in the bay and on the adjacent shelf during the spring to summer periods of 1999 and 2000, coincident with high carbon fluxes exported from the pelagic system to the sediment and favourable upwelling conditions. In the case of Concepción Bay, the rates of carbon loading to the sediment, during the summers of 1999 and 2000, were one order of magnitude higher than on the adjacent shelf, and determined a flocculent layer development in the benthic system. This flocculent layer, 5-6 cm of phytodetritus (C:N 6-7), represented between 60 and $75 \%$ of the Chl-a pool in the sediments and is associated with phytoplankton blooms and self deposition events during favourable upwelling periods (Graco et al., 2001). Seasonal upwelling locally modulates the amount of labile organic carbon in the surface sediments, with the exception of 1997 and the first half of 1998. During these periods, low values of sediment surface Chl-a were dominant in sediments, reflecting the low fluxes of carbon exported to the sediments (1997 and 1998, Fig. 3) and low PP rates. Additionally, the Chl-a content in the sediment was similar to the values observed during winter non-El Niño periods (e.g., July 1999, Fig. 3).
As well as the "pelagic-benthic" coupling changes during favourable and non favourable upwelling periods non-El Niño periods and during the 1997-1998 El Niño event, the interaction between the benthic and the pelagic systems also changed. The nitrogen exchange (ammonium) across the sediment-water column interface, showed the same pattern than the carbon fluxes exported to the sediment with a seasonal behaviour, both in Concepción Bay and on the adjacent continental shelf, during 1999 and 2000. During upwelling favourable periods of non-El Niño years (e.g., 1999), when the highest carbon fluxes were observed, the sediments act as an important source of nitrogen for the water column. During winter of the same years a lower ammonium exchange was observed, and sediment may act as a nitrogen sink (Table 1). The data suggest that the sediments of the central Chile upwelling system act as a large ammonium source or sink, respectively, depending principally on the amount of labile organic carbon reaching the sediments.

During 1998, the seasonal behavior disappeared and low ammonium fluxes were observed, both during summer and winter. This low exchange across the sediment-water interface could be associated with El Niño-induced changes in oceanographic conditions, and carbon fluxes exported to the area. In fact, the low nitrogen exchange between the sediment and the water column reflected the low organic matter load to the sediments during the 1997-1998 El Niño, which was coincident with low organic matter remineralization (ammonification and sulfate reduction rates) during this period (Graco, 2002; Farías et al., 2004).

\section{Conclusions}

Our results indicate that the pelagic and benthic systems off central Chile $\left(36^{\circ} \mathrm{S}\right)$ are tightly coupled. The organic matter flux to the benthos and the ammonium cycling at the sediment-water interface responds to the ENSO-related oceanographic variability as well as to the seasonal regime of upwelling during non-El Niño years. During the upwelling favourable periods of 1999 and 2000 a higher organic matter export from the water column to the sediment and a significant ammonium release from the sediments were observed. However, during the 1997-1998 El Niño event, when the oxygen availability increased while the temperature and nitrate concentrations decreased, the pelagic-benthic coupling was substantially modified. The carbon fluxes exported to the sediment diminished significantly during 1997 and the first half of 1998, with similar values than those observed during the winter of non-El Niño years. Moreover, coincident with a decrease in the sediment organic matter content and quality, the sediments which usually constitute an ammonium source for the water column, behaved as a sink of ammonium. 
Acknowledgements. This study was supported by grants from the Chilean National Fund for Scientific and technological Research (FONDECYT 198-0544) and the COPAS Program in Oceanography and Marine Biology. The first author thanks the financial support of the EU-project CENSOR (Climate variability and El Niño Southern Oscillation: Impacts for natural resources and management, contract 511071) and is CENSOR publication 0007.

Edited by: P. Fabian and J. L. Santos

Reviewed by: W. Arntz and another referee

\section{References}

Ahumada, R. and Chuecas, L.: Algunas características hidrográficas de la Bahía de Concepción $\left(36^{\circ} 40^{\prime} \mathrm{S} ; 73^{\circ} 02^{\prime} \mathrm{W}\right)$ y áreas adyacentes, Chile, Gayana Miscelanea, 8, 1-56, 1979.

Ahumada, R., Matrai, P., and Silva, N.: Phytoplankton biomass distribution and relationship to nutrient enrichment during an upwelling event off Concepción Bay, Chile, Boletin de la Sociedad Biológica de Concepción, 62, 7-19, 1991.

Arcos, D. F. and Salamanca, M. A.: Distribución de clorofila y condiciones oceanográficas superficiales frente a Chile central (Latitudes de $32^{\circ}-36^{\circ} \mathrm{S}$, Febrero 1982), Biología Pesquera, 13, 5-14, 1984.

Arcos, D. F. and Wilson, R. E.: Upwelling and distribution of Chla within the Bay of Concepción, Chile, Estuarine, Coastal and Shelf Science, 18, 25-35, 1984.

Barber, B. B. and Chavez, F. T.: Biological consequences of El Niño, Science, 222, 1203-1210, 1983.

Barber, B. B. and Chavez, F. T.: Ocean variability in relation to living resources during the 1982-1983 El Niño, Nature, 319, 279285, 1986.

Bernal, P., Ahumada, R., González, H., Pantoja, S., and Troncoso, A.: Flujo de carbono en un modelo trófico pelágico para Bahía de Concepción, Chile, Biología Pesquera, 18, 5-14, 1989.

Chavez, F. P., Pennington, J. T., Castro, C. G., Ryan, J. P., Michisaki, R. P., Schlining, B., Walz, P., Buck, K. R., McFayden, A., and Collins, C. A.: Biological and chemical consequences of the 1997-1998 El Niño in central California waters, Science, 54, 205-232, 2002.

Daneri, G., Dellarossa, V., Quiñones, R., Jacob, B., Montero, P., and Ulloa, O.: Primary production and community respiration in the Humboldt current system off Chile and associated areas, Mar. Ecol. Prog. Ser., 197, 41-49, 2000.

Escribano, R., Daneri, G., Farías, L., Gallardo, V. A., González, A., Gutiérrez, D., Lange, C. B., Morales, C., Pizarro, O., Ulloa, O., and Braun, M.: Biological and chemical consequences of the 1997-1998 El Niño in the Chilean coastal upwelling system: a synthesis, Deep-Sea Res. II (Topical studies in Oceanography, Oceanography in the eastern South Pacific), 51, 23892411, 2004.

Farías, L., Chuecas, L., and Salamanca, M. A.: Flujos de amonio a través de la interface agua-sedimento de Bahía Concepción (Chile centro-sur): Mecanismos de intercambio químico, Gayana Oceanología, 3, 99-118, 1995.

Farías, L., Graco, M., and Ulloa, O.: Temporal variability of nitrogen cycling in the continental-shelf sediments of the upwelling ecosystem off central Chile, Deep-Sea Res. II (Topical studies in Oceanography, Oceanography in the eastern South Pacific), 51, 2491-2505, 2004.
Fonseca, T. and Farías, M.: Estudio del proceso de surgencia en la costa chilena, utilizando percepción remota, Investigación Pesquera, 34, 33-46, 1987.

Fossing, H., Gallardo, V. A., Jørgensen, B. B., Huettel, M., Nielsen, L. P., Schulz, H., Canfield, D. E., Foster, S., Glud, R. N., Gundersen, J. K., Kuver, J., Ramsing, N. B., Teske, A., Thamdrup, B., and Ulloa, O.: Concentration and transport of nitrate by the mat-forming sulphur bacterium Thioploca, Nature, 374, 713715, 1995.

Graco, M.: Sedimentos del área de surgencia costera de Chile central $\left(36^{\circ} \mathrm{S}\right)$ : Fuente o sumidero de nitrógeno? $\mathrm{PhD}$ Thesis, Depto de Oceanografía, Concepción, 2002.

Graco, M., Farías, L., Molina, V., Gutiérrez, D., and Nielsen, L. P.: Massive developments of microbial mats following phytoplankton blooms in a naturally eutrophic bay: Implications for nitrogen cycling, Limnol. Oceanogr., 46, 821-832, 2001.

Gutiérrez, D.: Tasas de bioperturbacion en sedimentos de un area de surgencias de Chile central $\left(36^{\circ} \mathrm{S}\right), \mathrm{PhD}$ Thesis, Departamento de Oceanografía, Concepción, 2000.

Gutiérrez, D., Gallardo, V. A., Mayor, S., Neira, C., Vásquez, C., Sellanes, J., Rivas, M., Soto, A., Carrasco, F., and Baltazar, M.: Effects of dissolved oxygen and organic matter reactivity on macrofaunal bioturbation potential in sublittoral bottoms off central Chile during 1997-1998 El Niño, Mar. Ecol. Prog. Ser., 202, 81-99, 2000.

MacPhaden, M. J.: Genesis and evolution of the 1997-1998 El Nino, Science, 283, 950-954 1999.

Molina, V.: Flujos de Nitrgeno Orgnico Disuelto (NOD), un indicador de la capacidad degradadora de los sedimentos costeros de Chile central $\left(36^{\circ} \mathrm{S}\right)$, Master Thesis, Department of Oceanography, Concepción, Chile, 152 pp., 2002.

Neira, C., Sellanes, J., Soto, A., Gutiérrez, D., and Gallardo, V. A.: Meiofauna and sedimentary organic matter off central Chile: respone to changes caused by the 1997-1998 El Niño, Oceanologica Acta, 24, 313-328, 2001.

Pantoja, S., González, H., and Bernal, P.: Size-fractioned photoautotrophic production in a shallow bay, Biología Pesquera, 16, 99105, 1987.

Peterson, W. T., Arcos, D. F., McManus, G. B., Dam, H., Bellantoni, D., Johnson, T., and Tiselius, P.: The nearshore zone during coastal upwelling: daily variability and coupling between primary and production of Central Chile, Prog. Oceanogr., 20, 140, 1988.

Shaffer, G., Hormazabal, S., Pizarro, O., and Salinas, S.: Seasonal and interannual variability of currents and temperature off central Chile, J. Geophys. Res., 104, 29 951-29 961, 1999.

Shaffer, G., Pizarro, O., Djurfeldt, L., Salinas, S., and Rutllant, J.: Circulation and low-frequency variability near the Chilean coast: remotely forced fluctuations during the 1991-92 El Niño, J. Phys. Oceanogr., 27, 217-235, 1997.

Sobarzo, M. S., Figueroa, D., and Arcos, D. F.: The influence of winds and tides in the formation of circulation layers in a bay, a case study: Concepción Bay, Estuarine, Coast. Shelf Sci., 45, 729-736, 1997.

Strub, P. T., Mesías, J. M., Montecino, V., Rutllant, J., and Salinas, S.: Coastal ocean circulation off western South America, Coastal Segment $(6, \mathrm{E})$, in: The Sea, edited by: Robinson, A. R. and Brink, K. H., Wiley, New York, pp. 273-313, 1998.

Sun, M.-Y., Aller, R. C., and Lee, C.: Spatial and temporal distributions of sedimentary chloropigments as indicators of benthic processes in Long Island Sound, J. Mar. Res., 52, 149-176, 1994. 